\title{
Upaya Departemen Marketing Communication dalam Membangun Engagement (Studi Kasus pada Instagram @ musllimahdailycom)
}

\author{
Rizka Amalia $^{1}$, Yugih Setyanto ${ }^{2 *}$, Nigar Pandrianto ${ }^{3}$ \\ ${ }^{1}$ Fakultas Ilmu Komunikasi, Universitas Tarumanagara, Jakarta \\ Email: amaliarizkaaaaaa@gmail.com \\ ${ }^{2}$ Fakultas Ilmu Komunikasi, Universitas Tarumanagara, Jakarta* \\ Email:yugihs@fikom.untar.ac.id \\ ${ }^{3}$ Fakultas Ilmu Komunikasi, Universitas Tarumanagara, Jakarta \\ Email: nigarp@fikom.untar.ac.id
}

Masuk tanggal: 15-12-2021, revisi tanggal: 06-01-2022, diterima untuk diterbitkan tanggal: 16-01-2022

\begin{abstract}
Muslimahdaily.com makes Instagram a means to communicate with the public. This research was conducted with the aim of finding out what efforts the Marketing Communication team has made in building engagement on Instagram, knowing the content strategy of the Marketing Communication team in building Instagram engagement, knowing the content preferences of @ Muslimahdailycom followers. The theory used in this research is communication, computer mediated communication $(C M C)$, social media. This research uses a qualitative approach with a case study method. Data obtained by conducting observations, interviews, documentation. The results obtained through the research are First, to interact. Second, collaborate with influencers. Third, the type of content that @Muslimahdailycom followers like the most is Islamic content.
\end{abstract}

Keywords: engagement, Instagram, marketing communication

\begin{abstract}
Abstrak
Muslimahdaily.com menjadikan Instagram sebagai sarana untuk beromunikasi dengan publiknya. Penelitian ini dilakukan dengan tujuan untuk mengetahui upaya apa yang dilakukan team Marketing Communication dalam membangun engagement di Instagram, mengetahui strategi konten team Marketing Communication dalam membangun engagement Instagram, mengetahui preferensi konten followers@Muslimahdailycom. Teori yang digunakan dalam penelitian ini adalah komunikasi, computer mediated communication (CMC), media sosial. Penelitian ini menggunakan pendekatan kualitatif dengan metode studi kasus. Data diperoleh dengan melakukan observasi, wawancara, dokumentasi. Hasil yang diperoleh melalui penelitian adalah Pertama, melakukan interaksi. Kedua, melakukan kerjasama dengan influencer. Ketiga, jenis konten yang paling disukai oleh followers@Muslimahdailycom adalah konten islami.
\end{abstract}

Kata Kunci: marketing communication, engagement, Instagram

\section{Pendahuluan}

Pesatnya perkembangan teknologi informasi dan komunikasi membuat kemunculan internet sebagai media sosial. Media sosial dianggap sebagai perkembangan yang paling mutakhir dari teknologi-teknologi web baru berbasis internet karena dapat memudahkan orang untuk melakukan komunikasi, saling berbagi satu sama lain, berpartisipasi, bahkan membentuk sebuah jaringan secara online 
sehingga orang-orang bisa menyebarluaskan konten. Salah satu media sosial yang sering digunakan oleh masyarakat Indonesia adalah Instagram.

Instagram adalah media sosial berbasis gambar yang memberikan layanan berbagi foto atau video secara online (Mahendra, 2017). Banyak dari kalangan anakanak maupun orang dewasa menjadikan Instagram sebagai salah satu aktivitas seharihari mereka dan tidak sedikit sebagai bisnis atau hanya sekedar membagikan informasi contohnya seperti@Muslimahdailycom.

Berdasarkan data World Population Review, jumlah penduduk muslim di Tanah Air saat ini pada tahun 2020 mencapai 229 juta jiwa atau 87,2\% dari total penduduk 273,5 juta jiwa diantaranya adalah perempuan Muslim di Indonesia yang diantaranya bermain Instagram. @Muslimahdailycom memiliki followers di Instagram dengan rata-rata usia 16 - 25 tahun. @ Muslimahdailycom menggunakan Instagram untuk berinteraksi, membagikan foto atau video dan membagikan kontenkonten yang mereka buat. Dalam mengelola Instagram perlu membangun engagement di Instagram karena apabila engagement bagus tentu Muslimah di Indonesia akan tertarik dengan Instagram @ Muslimahdailycom. Salah satu yang mengelola Instagram @Muslimahdailycom adalah team Marketing Communication. Marketing Communication adalah tool yang digunakan untuk menginformasikan dan mendatangkan konsumen baik secara langsung maupun tidak langsung tentang suatu produk dan merek yang mereka jual (Kotler \& Keller, 2012).

Engagement merupakan kemampuan komunikasi sebuah brand yang melibatkan audience agar mempunyai ikatan dengan sebuah brand. Dalam mengelola Instagram upaya yang dilakukan oleh team Marketing Communication sangat berpengaruh dalam membangun engagement dari Instagram. Apabila engagement bagus, secara tidak langsung dapat mendorong followers untuk mengunjungi website Muslimahdaily.com. Karena perkembangan media sosial yang begitu pesat, Muslimahdaily.com menjadikan Instagram sebagai sarana untuk berkomunikasi dengan publiknya.

Muslimahdaily.com merupakan sebuah portal informasi online yang mewartakan dunia Muslimah Indonesia. Menyajikan informasi, pengetahuan, gagasan yang dapat menginspirasi. Salah satu media Muslimahdaily.com untuk menyampaikan informasi adalah menggunakan media sosial Instagram. Penggunaan media sosial Instagram yang semakin berkembang menjadikan alasan dibuatnya Instagram @ Muslimahdailycom.

Instagram sebagai salah satu media sosial yang sedang diminati oleh masyarakat. Hasil dari data NapoleonCat.com yang diakses tanggal 24 Agustus 2021. Pada bulan Januari-Mei 2020 menunjukan bahwa jumlah yang menggunakan Instagram mencapai 69,2 juta (69.270.000) dengan mayoritas 52,6\% pengguna Instagram di Indonesia adalah perempuan diantaranya adalah Muslimah Indonesia. Dalam penelitian ini penulis ingin mengetahui upaya apa yang dilakukan team Marketing Communication @Muslimahdailycom untuk membangun engagement audiens di Instagram, mengetahui strategi yang dilakukan team marketing communication dan mengetahui jenis konten apa yang paling disukai oleh followers Instagram@Muslimahdailycom.

\section{Metode Penelitian}

Penelitian ini dilakukan dengan menggunakan penelitian deskriptif kualitatif. yang berlandaskan pada filsafat postpositivisme, digunakan untuk meneliti objek yang 
bersifat alamiah (eksperimen sebagai lawannya), dimana peneliti sebagai instrumen kunci, teknik pengumpulan data dilakukan secara triangulasi (gabungan), analisis data bersifat kualitatif, dan hasil penelitian kualitatif lebih menekankan makna dari pada generalisasi (Sugiyono, 2013:9).

Penelitian ini menggunakan metode studi kasus. Dalam melakukan penelitian ini penulis menggunakan pendekatan penelitian deskriptif kualitatif dengan metode studi kasus. Studi kasus adalah rangkaian kegiatan ilmiah yang dilakukan secara mendalam tentang peristiwa, aktivitas baik pada perorangan, sekelompok orang, lembaga, atau organisasi untuk menjelaskan proses bagaimana situasi tersebut terjadi (Rahardjo,2017).

Peneliti akan menggunakan teknik pengolahan dan analisis data dengan melakukan wawancara sebagai langkah awal kemudian penulis mulai mengolah dan menganalisis data untuk mendapatkan kesimpulan dari upaya team Marketing Communication dalam membangun engagement di media sosial Instagram. Penelitian ini yang menjadi objek adalah media sosial Instagram @Muslimahdailycom dan yang menjadi subjek adalah team Marketing Communication.

\section{Hasil Temuan dan Diskusi}

Saat ini Instagram sedang diminati oleh banyak khalayak, Muslimahdaily.com memanfaatkan Instagram untuk memberikan edukasi atau inspirasi kepada Muslimah Indonesia yang ingin tahu tentang dunia Islam seperti fikih, sirah nabawiyah dan juga lifestyle tetapi dalam konteks islami agar audiens tidak merasa kaku apabila melihat Instagram@Muslimahdailycom sehingga@Muslimahdailycom bisa diterima oleh khalayak luas yang belum berhijrah maupun yang belum memakai hijab.

Oleh sebab itu di Instagram perlu membangun engagement karena apabila engagement bagus tentu Muslimah di Indonesia akan tertarik dengan Instagram @ Muslimahdailycom. Engagement merupakan salah satu indikator penting dalam Instagram, agar strategi yang dilakukan dalam mengelola Instagram mampu dilakukan dengan baik sehingga dapat terus berkembang. Tentu dalam membangun engagement tersebut perlu melakukan upaya. Menurut Marketingcraft.getcraft.com indikator yang digunakan untuk mengetahui tingkat engagement adalah Conversation yang berarti aktivitas percakapan di antara pengguna seperti comment, Amplification yang berarti penyebaran atau perluasan pesan seperti share, dan yang terakhir Applause yang berarti aktivitas respon singkat yang diberikan lewat fitur yang ada seperti like dan memberikan emoji.

Bedasarkan data yang diperoleh dari Narasumber, Rosyidah yang merupakan team Marketing Communication mengatakan bahwa upaya yang dilakukan untuk membangun engagement Instagram @Muslimahdailycom adalah team Marketing Communication@Muslimahdailycom selalu melakukan briefing terlebih dahulu untuk menentukan tema apa yang akan digunakan dalam membuat konten di Instagram agar tema tersebut relate dengan keadaan Muslimah saat ini. Contohnya seperti berita atau tren yang sedang hype pada saat ini tetapi dalam konteks yang positif. Sebelum digunakan tentu team Marketing Communication @Muslimahdailycom tidak langsung menggunakan tema tersebut tetapi melakukan pengecekan terlebih dahulu ada hal yang perlu di revisi atau tidak.

Lalu membuat postingan yang lebih visual karena foto atau video adalah tipe konten yang paling banyak mendapatkan respon karena mudah dilihat, hal ini dapat membuat audiens terhubung secara emosional. Dalam setiap postingannya, 
@Muslimahdailycom selalu memakai warna pastel dan menggunakan visual perempuan Muslimah untuk kontennya di feeds maupun stories. @Muslimahdailycom merasa bahwa perempuan cenderung lebih menyukai karakter yang lucu dan warnawarna soft. Hal ini bertujuan agar audiens merasa tertarik dengan feeds Instagram @ Muslimahdailycom.

Dalam mengelola Instagram, @Muslimahdailycom harus up to date terhadap berita atau tren yang sedang viral baik dari berita maupun selebriti. Karena konten akan menarik apabila relate dengan keadaan terkini. Ini akan menimbulkan persepsi bahwa Instagram @ Muslimahdailycom selalu menyajikan hal up to date yang dimana hal ini banyak disukai oleh audiens.

Seringnya melakukan question and answer (qna) atau quiz melalui Instagram stories adalah followers dapat bertanya perihal apapun dan kemudian @Muslimahdailycom menjawab, bisa juga dengan memberi pertanyaan quiz dengan tema yang sudah ditentukan kemudian followers menjawab dan dari pertanyaan atau jawaban tersebut @Muslimahdaily.com mengajak untuk berdiskusi agar followers dapat saling terlibat. Hal ini merupakan salah satu upaya yang team Marketing Communication@Muslimahdailycom lakukan guna membangun engagement di Instagram. Karena dari qna dan quiz dapat menimbulkan interaksi yang dimana followers akan merasa penasaran dengan pertanyaan-pertanyaan dan jawaban yang diberikan kemudian akan melihat stories hingga selesai. Hal ini dibuktikan reach yang paling banyak adalah stories qna dan quiz.

Instagram @Muslimahdailycom selalu mengajak followers untuk berinteraksi dengan berdiskusi melalui postingannya di feeds maupun stories. Interaksinya adalah dengan menanyakan bagaimana pendapat followers terhadap konten yang dibagikan melalui caption yang digunakan hal ini dapat menarik followers untuk ikut berkomentar pada setiap postingan yang dibagikan, kemudian mengajak followers untuk berdiskusi melalui DM atau comment dengan menggunakan caption yang bersifat mengajak karena hal ini dapat memberikan peluang agar konten yang dibagikan dapat diketahui banyak orang karena telah di share oleh followers secara sukarela, kemudian melakukan quiz atau sharing-sharing mengenai berbagai hal.

Followers Instagram @Muslimahdailycom yang sebagian besarnya adalah perempuan, membuat@Muslimahdailycom mengunduh konten yang dibutuhkan oleh perempuan, karena bisa jadi itu adalah solusi dari permasalahan yang sedang mereka hadapi, contohnya seperti tips and trick menggunakan make up tahan lama, doa-doa dalam melakukan sesuatu, mix and match pakaian yang ada unsur Muslimah, dan tips memakai skincare namun dialihkan menjadi "Skincare untuk merawat kulit \& wajah dengan produk halal" yang lebih mengarah ke islami. Hal ini juga yang membedakan Muslimahdaily.com dengan kompetitor lain, walaupun dikenal sebagai media islam tetapi prinsip dari Muslimahdaily.com adalah menyajikan konten dengan banyak variasi. Jadi walaupun memposting konten yang bersifat umum @ Muslimahdailycom tidak menghilangkan ciri khasnya yang berhubungan dengan Muslimah Indonesia.

Seringnya melakukan question and answer (qna) atau quiz melalui Instagram stories adalah followers dapat bertanya perihal apapun dan kemudian @ Muslimahdailycom menjawab, bisa juga dengan memberi pertanyaan quiz dengan tema yang sudah ditentukan kemudian followers menjawab dan dari pertanyaan atau jawaban tersebut@Muslimahdailycom mengajak untuk berdiskusi agar followers dapat saling terlibat. Hal ini merupakan salah satu upaya yang team Marketing Communication@Muslimahdailycom lakukan guna membangun engagement di Instagram. Karena dari qna dan quiz dapat menimbulkan interaksi yang dimana 
followers akan merasa penasaran dengan pertanyaan-pertanyaan dan jawaban yang diberikan kemudian akan melihat stories hingga selesai. Hal ini dibuktikan reach yang paling banyak adalah stories qna dan quiz.

Penggunaan hastag sangat penting agar audiens lebih mudah menemukan Instagram @ Muslimahdailycom. Tidak menggunakan hastag secara berlebihan dan populer, karena semakin populer suatu hastag akan lebih banyak yang menggunakannya. Instagram @Muslimahdailycom memilih menggunakan hastag yang sedikit dan dan unik. Maksud dari unik disini adalah yang menggambarkan ciri khas dari Instagram @Muslimahdailycom. Membangun engagement tidak hanya lewat feeds atau stories tetapi bisa melalui direct message (DM). @ Muslimahdailycom selalu berusaha menjawab pertanyaan-pertanyaan yang masuk perihal konsultasi atau media partner melalui direct message.

Penelitian yang telah peneliti dapatkan melalui wawancara dengan narasumber, didapatkan data Computer Mediated Communication (CMC). @Muslimahdailycom melakukan interaksi dengan mengajak followersnya untuk berdiskusi. Diskusi adalah bagian dari pola CMC dimana @Muslimahdailycom melakukan interaksi dengan followers yang didukung perangkat internet menggunakan media online yaitu Instagram. Dalam mengelola Instagram @ Muslimahdailycom team Marketing Communication telah melakukan semua upaya yang disebutkan di atas.

Menurut Arnus (2015) Computer Mediated Communication (CMC) adalah komunikasi yang dilakukan melalui komputer sebagai medianya. Secara sederhana dapat diartikan sebagai komunikasi yang dilakukan antara satu dengan yang lain menggunakan media komputer seperti perangkat personal (PC) atau laptop.

Dalam mengelola Instagram tentu tidak bisa asal dalam membagikan konten seperti foto dan video, namun diperlukan beberapa strategi untuk mencapai hasil yang maksimal. Di Instagram @Muslimahdailycom mempunyai beberapa strategi untuk membangun engagement di Instagram yaitu sebelum membuat konten biasanya team Marketing Communication melakukan riset terlebih dahulu terkait berita yang sedang hype pada masa kini, hal-hal yang sedang dicari, dan disukai oleh Muslimah Indonesia. Jika sudah melakukan riset baru konten itu dibuat dengan memerhatikan caption dan juga copywriting. Oleh sebab itu semua judul konten@Muslimahdailycom dibuat sedinamis mungkin.

Menggunakan caption yang menarik membuat followers @ Muslimahdailycom tertarik dengan konten yang dibagikan. Caption bisa berupa kalimat ajakan atau pertanyaan yang membuat followers meninggalkan komentar dalam caption yang dibuat. Dari komentar yang ada kemudian @Muslimahdailycom melakukan interaksi langsung dengan membalas komentar para followers.

Menentukan waktu yang tepat merupakan indikator penting dalam memposting konten di Instagram. Karena waktu yang sesuai dapat memberikan peluang konten yang dibagikan lebih dilihat oleh followers. Kemudian menggunakan fitur Swipe Up. Swipe Up adalah fitur yang yang bisa digunakan apabila mempunyai 10 ribu followers. Fitur Swipe $U p$ ini bisa memasukan link eksternal di stories. @Muslimahdailycom menggunakan fitur Swipe Up untuk mengarahkan followers untuk bisa langsung ke website Muslimahdaily.com agar followers lebih mudah untuk membacanya karena dengan klik link tersebut bisa langsung diarahkan ke website.

Mengetahui jenis konten yang paling disukai followers merupakan bagian penting dalam mengelola Instagram. Perlu mencari tahu karakteristik dari jenis konten seperti apa yang paling disukai oleh followers dan bagaimana strategi yang tepat. 
Misalnya, jika mayoritas audiens adalah perempuan maka lebih baik menggunggah konten seputar perempuan. Tujuannya agar lebih banyak audiens yang terlibat dan memberikan like, comment dan share. Penting untuk tahu bahwa tidak semua konten akan disukai oleh audiens, maka penting untuk memperhatikan jenis konten seperti apa yang memiliki engagement paling tinggi diantara yang lain.

Salah satu strategi Instagram @Muslimahdailycom adalah dengan bekerjasama dengan influencer. Kerjasama tersebut bisa dalam bentuk Live Streaming melalui media sosial Instagram Live atau melalui Webinar. Setiap bulannya @Muslimahdailycom selalu mengadakan kajian rutin melalui Live Streaming di Instagram atau Webinar dengan para influencer islami. Melalui influencer, Instagram @ Muslimahdailycom bisa berpeluang menjangkau audiens dengan skala yang lebih luas melalui followers yang dimiliki influencer tersebut.

Dalam membangun sebuah engagement di Instagram team Marketing Communication mempunyai enam strategi dan pada saat ini strategi yang sudah dijalankan adalah menggunakan caption semenarik mungkin dibuktikan dengan beberapa postingan dengan reach tertinggi karena menggunakan caption menarik yang membuat terjadinya interaksi antarafollowers dengan@Muslimahdailycom.

Penggunaan caption yang menarik strategi yang sudah dijalankan oleh @Muslimahdailycom dalam membangun engagement adalah dengan melakukan kerjasama antara @Muslimahdailycom dengan influencer. Hal ini dibuktikan setelah melakukan kerjasama dalam bentuk Live Instagram atau dengan Webinar, Instagram @Muslimahdailycom dibanjiri dengan comment, likes dan share yang dapat meningkatkan sebuat engagement.

@Muslimahdailycom memanfaatkan media sosial sebagai sarana memberikan edukasi dan inspirasi dengan melakukan Webinar dan Live Streaming bersama influencer. Menurut (Kotler \& Keller, 2012) Media Sosial adalah sebuah sarana bagi konsumen yang digunakan untuk berbagi informasi teks, gambar, video dan audio dengan satu sama lain.

Instagram@Muslimahdailycom memiliki berbagai macam konten yang informatif dan inspiratif diantaranya: konten islami (fikih, tips-tips islami), khazanah (pengetahuan seputar wawasan islam), lifestyle (gaya hidup tentang perempuan), kesehatan mental, quiz time, selebriti Indonesia. Karena Instagram @Muslimahdailycom merupakan ranah positif jadi konten yang membahas tentang selebriti Indonesia tetap ke arah yang positif dan tidak menyebarkan gosip.

Instagram@Muslimahdailycom memiliki jenis konten yang paling disukai oleh followersnya. Karena stigma @ Muslimahdailycom adalah islam jadi konten yang selama ini paling disukai oleh followers adalah konten yang berhubungan dengan dunia islam. Dibuktikan dari feedback yang di dapatkan berupa likes, comment dan share lebih banyak jika dibandingkan dengan konten-konten Instagram @ Muslimahdailycom yang lain.

Dilihat dari tindakan yang dilakukan oleh followers @Muslimahdailycom adalah bentuk feedback seperti likes, comment dan share. Comment dan like adalah bagian dari komunikasi yang mereka lakukan bahwa mereka menyukai konten tersebut. Interaksi yang dilakukan akan sangat mempengaruhi terhadap perkembangan engagement. 


\section{Simpulan}

Instagram Muslimahdaily.com untuk menyampaikan informasi kepada konsumen. Saat ini Instagram sedang diminati oleh banyak khalayak, Muslimahdaily.com memanfaatkan Instagram untuk memberikan edukasi atau inspirasi kepada Muslimah Indonesia. Dalam pengelolaan akun instagram @Muslimahdailycom, tim Marketing Communication perlu membangun sebuah engagement di Instagram agar dapat terus berkembang.

Dalam membangun engagement tersebut perlu melakukan berbagai upaya, strategi dan juga mengetahui karakteristik dari followers Instagram @Muslimahdailycom. Upaya yang dilakukan dalam membangun engagement adalah menentukan tema, membuat konten yang lebih visual, selalu up to date, melakukan qna, membangun engagement lewat direct message, melakukan interaksi, konsisten posting, menggunakan hastag, memanfaatkan fitur yang tersedia dan memposting konten yang dibutuhkan followers.

Dalam membangun engagement perlu adanya strategi seperti melakukan riset, menggunakan caption menarik, waktu posting yang tepat, memberikan edukasi, bekerjasama dengan influencer, memanfaatkan fitur swipe up dan konten yang paling disukai oleh followers Instagram @ Muslimahdailycom adalah konten yang membahas tentang islami.

\section{Ucapan Terima Kasih}

Pneliti mengucapkan terima kasih kepada Fakultas Ilmu Komunikasi Universitas Tarumanagara, narasumber, dan rekan-rekan yang telah mendukung setiap proses penelitian yang telah dilalui sampai penelitian ini selesai dengan baik.

\section{Daftar Pustaka}

Arnus, S. H. (2015). Computer Mediated Communication (CMC), Pola Baru Berkomunikasi. Al-Munzir, 8(2), 275-289.

Barus, K. (2020). Jumlah Penduduk Muslim Indonesia Meningkat, Power Commerce Asia Tangkap Peluang, Luncurkan Halal Plaza. 05 Mei 2020 $<$ https://www.industry.co.id/read/65748/jumlah-penduduk-musliimindonesia-meningkat-powercommerce-asia-tangkap-peluang-luncurkan-halalplaza>, diunduh tanggal 24 Agustus 2021.

Kotller, P. \& Keller, K. L. (2012). Manajemen Pemasaran Jilid 1 edisi 12. Jakarta: Erlangga.

Mahendra, Bimo. (2017). Eksistensi sosial media remaja dalam Instagram (sebuah perspektif komunikasi). Jurnal Visi Komunikasi. 16(1). 151-160.

Naim, N, (2016). Dasar-dasar Komunikasi Pendidikan. Yogyakarta: Ar-Ruzz Media. Rahardjo, Mudjia. (2017). Studi Dalam Penelitian Kualitatif: Konsep Dan Prosedurnya. Malang: Universitas Islam Negeri Maulana Malik Ibrahim.

Sugiyono. (2013). Metode Penelitian Kuantitatif Kualitatif dan $R \&$ D. Bandung: Alfabeta. 